\title{
RPHA 法による便潜血反応陽性者に 対する受診推奨の必要性
}

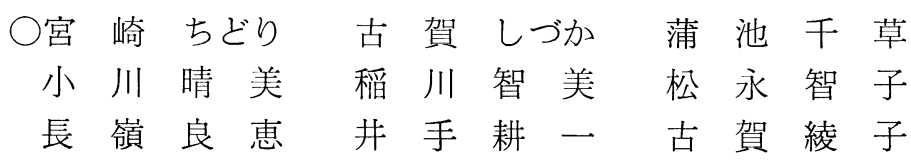

\section{1.はじめに}

聖マリア国際保健センターでは, 自動化健款システム により，年間約 6,000 名の人間ドック健診を実施すると 共に, 保健婦, 栄養士による健診後の事後指導や衛生教 育をはじめ要精検者に対する受診推奖にあたっている。

今回, 従来の便潜血反応に比較し, 有所見率が高い上 報告されている RPH A 法陽性者に対して積極的に，大 腸内視鏡検査を勧実施し高い有所見率之精密検査実施 体制化の成果を得たので報告する。

\section{2. 検 查結果}

1）便潜血検查結果及び大腸内視鏡検査結果

昭和 61 年 4 月から 11 月までのドック受診者の検便数 3, 885 件のうち，オルトトリジン法とグアヤック法で陽 性を示した検体 1,344 件において, RPHA 法による便 潜血検査を施行し陽性数 73 件， $5.4 \%$ であった。

RPHA 法による便潜血反応陽性者中 30 名に対し回盲 部までの大腸内視鏡検査が実施された。対象者は，40 歳から 59 歳までの男性が 23 名で全体の $77 \%$ を占めて いた。大腸内視鏡検查結果は異常なしが 4 名で，有所見 者では, 大腸ポリープが 18 名と最む多く全体の $60 \%$ を 占めていた。次いで痔疾患が 5 名で, 大腸癌は 30 名中 3 名で $10 \%$ を占めていた。また大腸ポリープの全患者 に対し組織診が行なわれているが, その結果, 約半数が tubular adenoma 飞分類され, 山田のIII型・IV型のポ リープに対してはポリペクトミーが施行された。

2) 癌症例 3 名について

第 1 例は 46 歳の男性で $\mathrm{S}$ 状結腸部の深達度 $\mathrm{M}$ 期の粘 膜内癌であったためポリペクトミーのみで軽快退院が可 能なケースであった。第 2 例は 50 歳の男性で, $\mathrm{S}$ 状結 腸部に Stage I の癌が認められ, 楔状切除術が行なわ れた。尚, 人工肚門の造設の必要はなく, 退院後は抗癌

\footnotetext{
Importance of Physical Check-up for the Stool Occult Blood Test (RPHA Method) Positive Case
}

聖マリア病院国際保健センター
剂を服薬している。

第 3 例は 67 歳の男性で Stage III のS 状結腸癌が発見 され，低位前方切除術と人工肛門造設術が行なわれた。

\section{3. 自動化健診における事後 Follow システム}

人間ドック受診後の事後 Follow システムとして要精 検や要治療の判定項目がある者に対して二次受診案内の 発送や電話による受診推奖を行っている。また，精密検 査や入院加療関して, 当センタ一の保健婦や事務スタ ッフにより, 聖マリア病院の外来, 病棟と連携をとって いる。RPHA 法による便潜血反応陽性者に対しては漏 れのない様に精密検査を勧めているが, 所属団体の保健 婦や, 衛生管理者を通じて, 受診勧奖を行う方が, 支障 なく受診するケースああり，団体，企業体との連携を今 後, より強化したい。

\section{4. 大腸内視鏡検查実施体制}

自動化健診システムにより，人間ドック受診日の午後 に, RPHA 法による便潜血反応の結果も含め, 約 9 割 の健㟝結果を医師より説明が行なわれる。便潜血陽性者 に対しては，人間ドック受㟝日当日に受㡣者の都合を聞 き, 精密検査実施日を予約する事になっている。また, 病院外来スタッフとの協力のもとに, 精密検査の内容及 び前処置の必要性等の説明を行っている。その後, 大腸 内視鏡検査を受診し組織検查のある者は約 1 週間後に結 果説明が行なわれる。大腸癌あるいはその他の疾患が発 見された者については, 入院加療がなされる。特別に異 常が認められなかった者については, 定期的な外来ある いは人間ドックを受診し, 経過を観ていくシステムであ る。

\section{5. まとめ}

自動化検診システムの導入と精密検査実施体制の整備 により, 便潜血陽性者に対する円滑な Follow up が可 能となり, 3 例の大腸癌症例を発見し入院加療まで運ぶ 事ができた。今後更に陽性者への受診推奖はもとより, 便潜血検査についての正しい知識の普及を含めた衛生教 育に努めたい。 